\title{
Financial Inclusion for Sustainable Economy: Empirical Evidence from Nigeria
}

\author{
FUNSO ABIODUN OKUNLOLA \\ Department of Banking and Finance \\ Covenant University \\ P.M.B 1023, Ota, Ogun State. \\ NIGERIA.
}

\author{
MICHAEL AKINADE ALATISE \\ School of Business, Department of Economics \\ University of Ibadan \\ Oyo State, \\ NIGERIA
OLAJUMOKE REBECCA OGUNNIYI
Department of Business Administration
KolaDaisi University
Ibadan, Oyo State
NIGERIA. \\ MOSES OLUKUNLE ADEJUMO \\ Department of Economics, \\ Lagos State University \\ Ojoo, Lagos state \\ NIGERIA
}

\begin{abstract}
The main objective of the study is to empirically examine how economic growth is impacted upon through financial inclusion. Economic growth per capital income is the study's explained variables while, rural deposits, private sector deposits, rural loans, private loans, and number of banks branches are proxies for the explanatory variable. Secondary data was sourced from the Central Bank of Nigeria statistical bulletin and World Bank financial indicator and span thirty-five years (1982 to 2017). From the augmented dickey fuller (ADF) test results, autoregressive distributed lag (ARDL) regression was adopted. Findings shows that individually, rural deposits, and number of banks branches are significant in the short-run while, only the former is significant in the long-run. However, jointly, and from the Wald test result, a no significant relationship is established between the variables in the long-run. The study thus recommends a nurturing approach from primary to tertiary level of financial inclusion.
\end{abstract}

Key-word: - Financial Inclusion, Per Capital Income, Economy, Growth, ARDL

Received: November 3, 2019. Revised: March 13, 2020. Accepted: March 31, 2020. Published: April 21, 2020. 


\section{Introduction}

Literally, exclusion precedes financial inclusion. By implication, exclusion means denial or inability to access existing or potential benefits. In order words, the more access to financial related products and services in a country, the likelihood of a country's potentials in achieving growth per capital. While the term (financial inclusion (FI)) has constituted heated debate in development finance lately, [1], [2], [3], Babajide, et al, [4], [5], [6], are considered as some of the discussants. Mainly, summation of these authors is that access to formal bank account opening, usage of banks products and services, quality of products offering, increase number of banks branches, increase in number of payment devices, public awareness to banks products and services and so on, constitute financial inclusion. In another clime, financial inclusion is weighted against average stock market index participants. This is used as a form of country's financial inclusion ranking [7],[8]. For instance, Standards and Poors (S\&P), Dow Jones, Nasdaq, Nasdaq, Nikkei and All Share Index (ASI) are used (but not sufficient) as measure of financial inclusions in some countries. Other measures relate to banking activities and macroeconomic indices, among others. In Nigeria, for example, records show that percentage of total adult population to savings account, loans access and payment system by year 2020 is targeted at 60,40 , and 70 percent respectively; an indication of the extent of depth in financial exclusion [9]. Also, deposit money banks branches is expected to have grown by 100,000 units per adult population to 7.6 percent, automated teller machine (ATMs) to 59.6 percent, point of sales (POS) to 85.0 percent and mobile banking to 62 percent by the same period. Though, present observations shows that there has been tremendous improvement in the number of access to financial products and services by citizens judging by the array of financial reforms to encourage such in the country, ranging from the cashless policy, to mandatory banks verification number, zero account opening initiative, establishment of interest-free banking and allied products, rural banking initiative, single-digit interest rate for onward lending to micro small and medium enterprises (MSME), among others $[2,4,5]$.

In spite of all, Global Findex database 2018 shows that only 39.4 percent of all adults has a formal account in the country and a gross national income per capital of $\$ 2,450$; compared to 67.4 percent all adults in South Africa with a gross national income per capital of $\$ 5,480$; and Libya of 65.7 percent all adults and gross national income of $\$ 4,730$. In the light of this, if the financial globe is seen to be like that of a moving train waiting for no one and, Nigeria needs to tap into the speed of opportunities then, there is need to accelerate its financial sophistication cum rapid economic growth per head that is evidenced in its all-inclusiveness financially. These pertinent but vital questions are germane: "how should authorities respond to the menace of making financial inclusion all-comers-affairs? And, what must be the role of the financial institutions to create and nurture to maturity financial inclusion? Without equivocation, the objective of the study is to empirically examine financial inclusion through the eye of its contribution to growth per capital income of the country. From the introduction follows the literature review. This is followed by methodology; next to this is the result and discussion, while conclusion and recommendation comes at the end.

\section{Problem Formulation}

What constitutes the meaning of financial inclusion in the literature is mixed. [6] says that, the use of formal financial products and services of a bank is financial inclusion, with a caveat that the term usage may differ across boundaries. Egharevba, et al, [10], [4] observed that the incidence of poverty has direct link with exclusion, as affected people do not have access to a wide range of financial services and products. [5] likened financial inclusion to hierarchy of financial needs. Accordingly, when one need is met, other needs immediately creep up to be met. The inability to participate in the progress of development in a country through its financial system leads to exclusion Muhammad,et al, [11]. Similarly, global community through its sustainable development goals (SDG's) admit that all-inclusiveness is key to reducing hunger, poverty, gender inequality, reduce inequality, job creation and economic growth among others.

Expectedly, with more access to formal financial services and products, especially lending, which is often at the intermediate or secondary stage of banks-customer relationship, affected and vulnerable people would be able to contribute to nation building, through the inter-link of investment activities. By implication, the more individual and groups have access to financial services and products, the better the improvement in the living standard and, ultimately, the better for overall economic growth $[10,4,12,13,14,3]$. 


\subsection{Financial Inclusion Process}

At the front-burner of ensuring financial inclusion for sustainable economic growth is the financial institutions (of which, the deposit money bank is vital), through monetary authority and government policy initiatives. Primarily, deposit money bank is an institution that mobilizes savings from the surplus side of the economy and lending same to the deficit unit. In the heart of this intermediation is the hierarchy of financial needs - account opening, lending, and business development [5]. In order words, the process of being financially inclusive begins with account opening access (both from rural and urban areas), where bank customerrelationship starts. This may be referred to as the primary/foundational stage of financial inclusion. At this level, customer enjoys preliminary/primary benefits of their inclusion such as friendly and regular phone conversion/relationship with their account officers, short message services (SMS) for credit and debit alert. Expectedly, this access to account opening should be natured such that qualifies customers to a post primary stage semiintimacy and business rapport relationship. That is, where a customer opens up on issues concerning his/her personal/business/financial ambition. This level is maturing beyond the ordinary primary friendship and could be term as the secondary level/stage of financial inclusion. Here, banks steps in and help to nurture the customer to realization of his/her personal/business/financial ambition. Some of the benefits associated with this stage are: all primary stage benefits plus, credit rating/potentials, loans/advances/overdraft access, debit card access, mobile transfer/POS and so on. After this level comes the post-secondary level. That is, the tertiary/advanced stage where customers would have been nurtured to maturity. For financial inclusion to be fully achieved, it is expected that all at the lower stance/primary hierarchical stage as opined by [5] be nurtured to maturity/tertiary level but; we doubt if this is ever the case. Some benefits associated with the tertiary level are: primary and secondary benefits, plus credit card, internet banking, and international banking among others.

\subsection{Deposit Money Banks and Financial Inclusion in Nigeria}

Intermediation function of deposit money banks aimed at all financial inclusiveness are;

\section{a. Rural Deposit Mobilization}

Deposit money banks in Nigeria practices branch type of banking, where it is allowed to have a full fledge bank branch or a cash centre located in the rural areas of the country. In over seven hundred and seventy four (774) Local Government Areas (LGA's) in Nigeria, not all deposit money banks presence is found in all. Often, the argument put forth lies in the competitive nature of these areas, their fewer population and possible banks oversaturation. This also includes poor or absence of basic infrastructural facilities, cum the literacy rate of those residing within this region. There is also the argument that similar cost would be required in setting up a branch in the LGA's with that of the urban centres, where aforementioned conditions are pretty present. Of course, the ability of the banks to mobilize maximum deposit will be contestable owing to these conditions, especially because of high rural-urban migration Andrew, et al, [15]. However, from the period under review, the study showed that deposit mobilized in the rural areas maintained an oscillatory movement all through 1982 to 2019. Specifically, it maintained consistent rise from 1982 to 1992 at between \#111.7 million to \#10,580.7 million. It slowed down in 1992 mainly because of the political tension at that time to \#4,612.2 million. Thereafter, it experienced an up/down movement till reaching its peak at \#359,389.8 million again in 2016 before nosediving in the following years up till 2019 because of the global financial crisis and the country's technical recession. Below is a graphical representation:

\section{Fig. 2, Deposit Money Banks Rural Deposits}

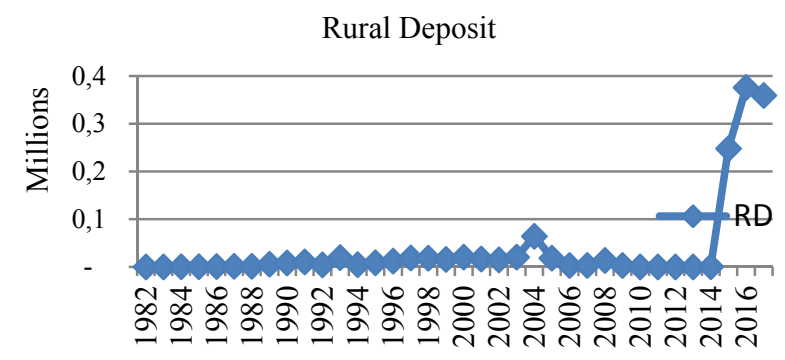

\section{b. Urban Deposit Mobilized}

Like most developed and emerging economies, the urban areas are where the highest population is found. Nothing is responsible for this than the presence of infrastructural facilities, high literate level, and industrial presence, compared with the rural areas. The implication of this is the fact that as more and more people trooped into the urban areas and becomes engaged in one activity or the other, there will be the need to access the bank either for primary purpose engagement or secondary and advanced purpose. Similarly, there 
will be the need for industrial expansion as more and more activities are been engaged in to satisfy the influx. This expansion is seismic in nature, that is, private and public expansion. Thus, banks intermediation at this level is at the peak $[10,16$, 4]. For the purpose of this study, deposit to the private sector is mirrored for urban deposit. A glimpse at figure 2.2 below shows that deposits in this area has maintained steady rise from the period under review. However, visible rise away from the steadiness came around 2003 to 2005 majorly as a result of the recapitalization reform at the time. Ever since that period, deposit mobilized by the Deposit Money Banks in this area has increased and maintained an upward rise level up till the present day. Below is a figure representing this illustration.

\section{Fig. 2, Deposit Money Banks Urban Deposits}

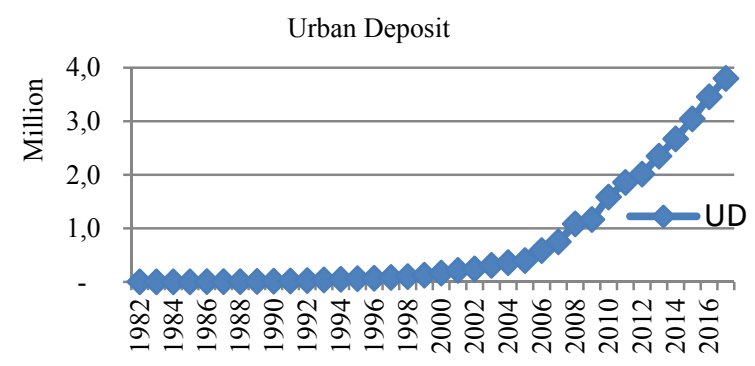

\section{c. Rural Loans of Deposit Money Banks}

Since available population in the rural areas is not comparable to that present in the urban areas, there will be minimal lending opportunities [15]. This is also coupled with the fact that most industries are located in the urban areas. In the rural areas, most commonplace business venture found is the micro/small scale business often in agro-allied and, the population are considered poor, often unable to provide banks lending conditions [4]. Unless and except there is deliberate policy direction in this regard, banks will always avoid lending to rural dwellers. In fact, to the banks, it is not a good profit centre. As a result, rural loans of Deposit Money Banks as depicted in figure 2.3 below shows that credit to this area has been abysmally small, maintaining an amount averaging less than a hundred million for more than two decades (i.e. 1982 to 2012), [17].

\section{Fig. 3, Rural Loans of Deposit Money Banks}

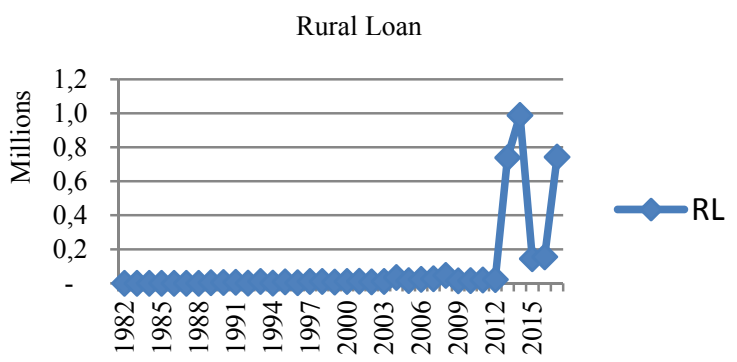

\section{d. Urban Loans of Deposit Money Banks}

Because of the magnitude of financial related activities in the urban centres, banks intermediation process is fully operational in these areas. Unlike credit available to the rural areas, urban centres are beehives of business activities requiring regular and constant financial lubrication. This is evidence from the number of individuals, groups or corporate organization requesting credit on a daily basis for stocks replenishment, business expansion, and purchase of raw materials among others. In similar like fashion, the study shows that loans available to the urban centres indicate oscillatory movement for the period under review and as review from the Central Bank of Nigeria statistical report. From figure 2.4 below, loans to the urban areas peaked between 2006 to early 2008. The successful recapitalization exercise of the banking sector between 2003 and 2005 may be adjudged the reason for this rise. However, it soon nosedived in the better part of same year owing to global financial crises and the recession experienced by the country. .

Fig. 4, Rural Loans of Deposit Money Banks

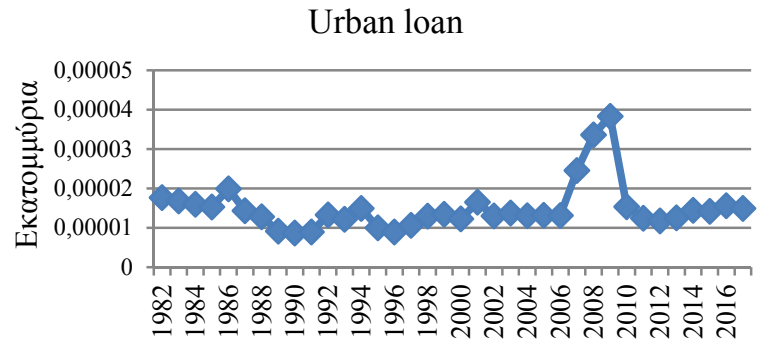

\section{e. Number of Banks Branches}

There are two aspects to the issues of bank branches in Nigeria. First is the regulatory aspect which, stipulates, depending on the banking license acquired (Local, National or International) that, banks, must satisfy its core function by providing public financial needs by operating one main head office and have several other branches within its 
jurisdiction of operating license. Second, is the bank independent feasibility study of profit centres (i.e. areas/locations/region), which it sees as investment opportunity. The latter is more of concern to the bank than the former which, to a great extent, informs the reason for setting up banks branches in profitable locations. This is also a scenario responsible for possible overconcentration of banks branches within one geographical region than the other. Without doubt, the number of Deposit Money Banks branches has increased over the years compared to its past days, especially as economic activities expands across initially low profit centres. This is corroborated in World Bank Global Findex data of 2018, which indicate that Deposit Money Banks branches has grown in number from its initial nine hundred and ninety-one (991) branches in 1982, up to fifty-five thousand seven hundred and fourteen $(55,714)$ in 2017. However, this is still just 7.6 percent per 100,000 thousand adult populations [18]. Figure 2.4 below shows the chart trend.

\section{Fig. 5, Rural Loans Deposit Money Banks}

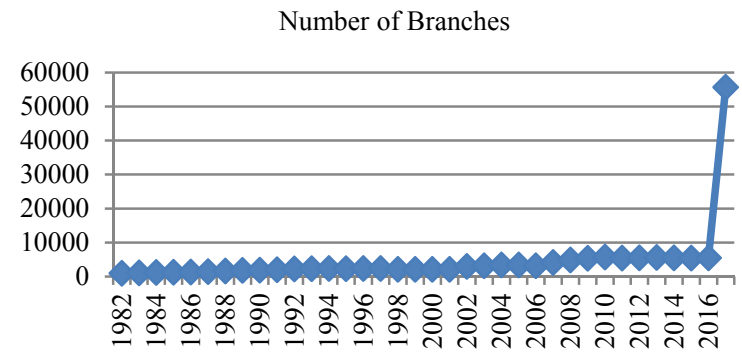

\section{f. Economic Growth Per Capital Income}

A measure of a country's productive income in relation to its population is referred to as gross domestic product per capital income. Simply put, it is. $\frac{G D P}{\text { Population }}$, which is used to determine or measures a country's standard of living. On the average, a continuous rise in this volume means improvement in a country's living standard; while a decline means reverse is the case. For the study, economic growth per capital from the period in review shows somewhat relative stable and steady growth over time. Particularly, there was a steady rise in early 1982 with minor fluctuations between1986 to 1990. This period witnessed the devaluation of the country's currency. It increased further between 2003 and peak in 2005/06, and it has maintained a steady but minimal increase in spite of the global recession and economic recession, up until the present day.

Fig. 6, Economic Growth Per Capital Income

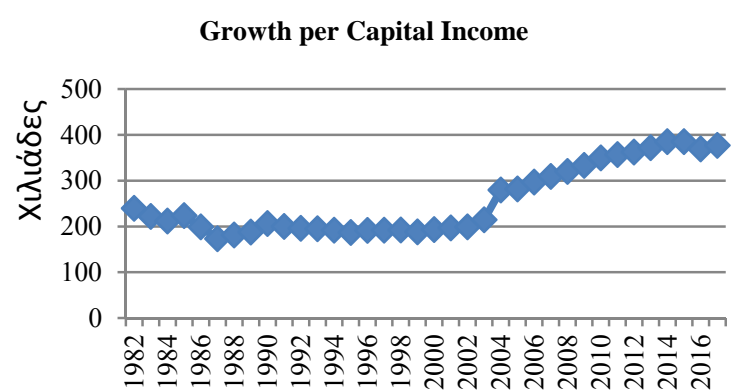

Fig. 7, Conceptual Framework of Financial Inclusion Process - The Link Chain

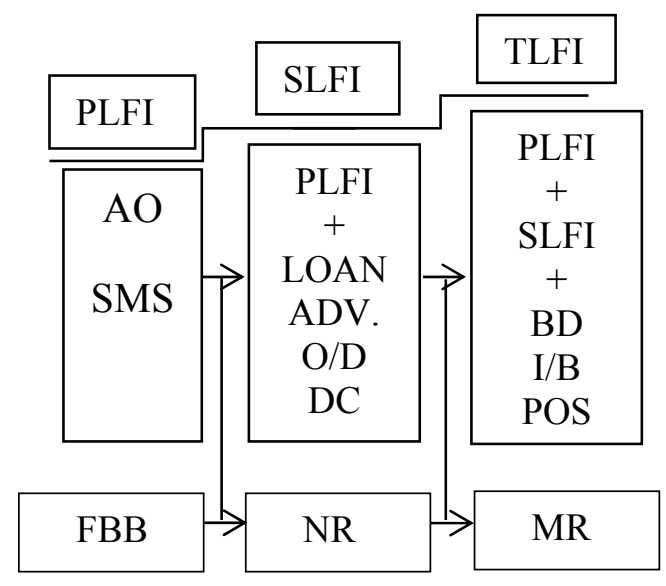

Where:

PLFI $=$ Primary Level of Financial Inclusion.

SLFI $=$ Secondary Level of Financial Inclusion

TLFI $=$ Tertiary Level of Financial Inclusion

$\mathrm{AO}=$ Account opening

SMS $=$ Short Message service

$\mathrm{AD}=$ Advance

$\mathrm{OD}=$ overdraft

$\mathrm{DC}=$ Debit card

$\mathrm{BD}=$ Business Development

$\mathrm{I} / \mathrm{B}=$ Internet Banking

POS $=$ Point of Sales.

FBB $=$ Foundational Building Block

$\mathrm{NR}=$ Nurturing Relationship

$\mathrm{MR}=$ Matured Relationship

\subsection{Empirical Review}

$\mathrm{Ab}$ initio, most studies on the impact of financial inclusion on economic growth agrees to the fact that significant relationship exists between them. For instance, [4] summation on whether financial inclusion is a factor determining factor production is positive and statistically significant. [5] study 
used ordinary least square at determining the relationship between financial inclusion and economic growth in Nigeria. Again, his result, though positive, but marginally influence economic growth. Re-appraising the Millennium Development Goals (MDG's) aimed at allinclusiveness, poverty reduction, income inequality among others was the bane of [10] study. Accordingly, the explanatory study confirmed the reason why nations should be allowed to take actions concerning their all-inclusiveness without external interference. [16] also opined that exclusion in South Africa is as a result of level of education, income sources, age and high number of dependants. From the logistic regression used for the study, educational level attainment is at the bottom of pyramid of financial excluded citizens. [13] study on India and France admit that larger population in these countries is financial excluded owing to the rise in livelihood insecurity of the working class, with its attendant effects on their banking behaviour. By implication, it is expected that proper policy aimed at improving on financial inclusion be put in place. [3] used primary and secondary data to determine the relationship between financial inclusion through insurance and pension schemes in India. Their study confirmed the importance of financial inclusion to solving inclusive welfare activities of the farmers in this regard. [2] study also attested to the fact that financial inclusion is an instrument to combating poverty in Ekiti state. From their 180 randomly selected sample of adult households (male and female), findings shows that poverty rate was higher among women population. Studies like Andrew, et al, [15], [19], [20] [21], [12]; [11], [1] are among similar authors with positive and significant relationship between financial inclusion and economic growth.

\section{Problem Solution}

The study took a point of divergence from the commonly adopted survey methodology to this type of work by adopting a descriptive and a time trajectory approach of act capable of improving financial inclusion. This new path stem from the works of [4] [5]. Specifically, Skewness, kurtosis and Jarque-Bera formed the descriptive tools used. While Wald test, cumulative sum (CUSUM), t-test, error correction mechanism (ECM) through the path of estimating Autoregressive distributed lag (ARDL) is also used because of the stationary status exhibited by the variables. Data set for the study is sourced from the Central of Bank of Nigeria 2018 statistical bulletin, and covers trigintasex (1982 - 2018) period. E-views statistical software is used for the estimation

\subsection{Model Specification}

In its natural mathematical function, the study specified as follows;

$\mathrm{PCI}=\mathrm{f}(\mathrm{FI})$

Where; PCI $=$ Per capital Income and FI = Financial inclusion.

If this is expanded it becomes;

$P C I=f(R D, U D, R L, U L, N o B B)$

Where, $\mathrm{RD}=$ rural deposit; $\mathrm{UD}=$ urban deposit; $\mathrm{RL}=$ rural loan; $\mathrm{UB}=$ urban loan; $\mathrm{NoBB}=$ Number of banks branches.

When transformed into its econometrics model, it becomes;

$\mathrm{PCI}=\alpha+\delta \mathrm{RD}+\delta \mathrm{UD}+\delta \mathrm{RL}+\delta \mathrm{UL}+\delta \mathrm{NoBB}+\mu_{\mathrm{t}}$ (3)

Where: $\alpha=$ is the intercept, $\delta=$ parameter of the estimates and, $\mu_{\mathrm{t}}=$ error term

\subsubsection{Descriptive Model Specified}

Skewness: $\mathrm{Sk}=\frac{\sum \mathrm{f}(\mathrm{X}-\boldsymbol{\mu} \rrbracket \mathbf{3}}{\sigma \mathbf{3}}$

Where: $\mathrm{Sk}=$ Skewness; $\mathrm{X}=$ mean of distribution; $\mu$ $=$ parameter $\boldsymbol{\sigma}=$ standard deviation

Decision Criterion: $\mathrm{Sk}=[(0)=$ symmetric $(+)=$ long right tail; $(-)=$ long left tail]

Kurtosis $=$ Kurtosis $=\frac{\sum \mathrm{f}(\mathrm{X}-\boldsymbol{\mu}) \mathbf{4}}{\boldsymbol{\sigma 4}}$

Decision Criterion: [ $3=$ Mesokurtic; $>3=$ Peak (Leptokurtic); $<3$ = flat (Platykurtic]

Jarque - Bera Stats $=J B=n\left[\frac{(N b 1) 2}{6}+\frac{(b 2-3) 2}{24}\right]$

Decision Criterion: where: $\mathrm{b} 1=$ sample skewness coefficient, b2 $=$ kurtosis coefficient

\subsubsection{Unit Root Test}

$\mathrm{Ab}$ initio the order of integration of the individual series is tested owing to the non stationarity characteristics of most time series data. The estimation equation is as given below $[22,23,24]$. $\Delta \mathrm{Y}_{\mathrm{t}}=\beta_{1}+\beta_{2} \mathrm{t}+\delta \mathrm{Y}_{\mathrm{t}-1}+\Sigma \alpha \mathrm{i} \Delta \mathrm{Y}_{\mathrm{t}-\mathrm{I}}+\varepsilon_{\mathrm{t}}$

Where: $\varepsilon_{\mathrm{t}}=$ is a residual time; $\mathrm{Y}_{\mathrm{t}}=$ is the relevant time series; $E_{\mathrm{t}}=$ random error term

\subsubsection{Autoregressive Distributed Lag (ARDL) Model Specified}

In the general form of an ARDL (p, q1,q2 ...qn) model based on equation i outcome, we specify; 
$\Delta \Psi_{\mathfrak{t}}=\beta_{0}+\sum_{i=1}^{n} \beta \mathrm{i} \Delta \Psi_{\mathfrak{t}}-1+\sum_{i=0}^{n} \lambda \mathrm{i} \Delta \chi_{\mathfrak{t}}-\mathrm{i}+$ $\Omega_{1} \Psi_{\mathfrak{t}-1}+\Omega_{\mathrm{n}} \chi \mathrm{t}^{-1}+\mu_{\mathrm{t}}(8)$

Where: $\sum_{i=1}^{n} \beta 1 \Delta \Psi_{\mathfrak{t}}-1+\sum_{i=0}^{n} \lambda 1 \Delta \chi_{\mathfrak{t}}-1$ is the short run model and $\Omega_{1} \Psi_{\mathrm{t}-1}+{ }^{\prime} \Omega_{\mathrm{n}} \chi_{\mathrm{t}-1}$ is the long run model of the equation. That is, $\beta_{1} \ldots \lambda_{1}$ are the shortrun coefficients of the model; while ' $\Omega_{1} . . \Omega_{n} \ldots$ are the ARDL long-run coefficients and $\mu_{t}$ is white noise term [25].

\subsection{Results and Discussion}

\begin{tabular}{l|l|l|l|l|l|l}
\hline \multicolumn{7}{l}{ Table 1, Descriptive Result } \\
\hline & PCI & RD & UD & RL & UL & NOBB \\
\hline & & & & & & \\
\hline Mean & 254511.6 & 36000.05 & 741.2787 & 86493.55 & 14.98806 & 4548.861 \\
\hline Median & 213241.5 & 7041.050 & 145.8876 & 11154.45 & 13.41000 & 2405.000 \\
\hline Maximum & 385228.0 & 376308.9 & 3800.100 & 988587.9 & 38.35000 & 55714.00 \\
\hline Minimum & 173012.0 & 19.72322 & 2.321200 & 35.90000 & 8.690000 & 991.0000 \\
\hline Std. Dev. & 74874.82 & 91598.97 & 1102.890 & 230597.8 & 6.052701 & 8911.430 \\
\hline Skewness & 0.637414 & 3.089845 & 1.498064 & 3.032377 & 2.487290 & 5.467567 \\
\hline Kurtosis & 1.736666 & 11.02469 & 3.977655 & 10.72680 & 9.524186 & 31.94113 \\
\hline Jarque-Bera & 4.831802 & 153.8763 & 14.89889 & 144.7270 & 100.9672 & 1435.749 \\
\hline Probability & 0.089287 & 0.000000 & 0.000582 & 0.000000 & 0.000000 & 0.000000 \\
\hline & & & & & & \\
\hline Sum & 9162416. & 1296002. & 26686.03 & 3113768. & 539.5700 & 163759.0 \\
\hline Sum Sq. & $1.96 \mathrm{E}+11$ & $2.94 \mathrm{E}+11$ & 42572832 & $1.86 \mathrm{E}+12$ & 1282.232 & $2.78 \mathrm{E}+09$ \\
\hline Dev. & & & & & & \\
\hline $\begin{array}{l}\text { Observatio } \\
\text { ns }\end{array}$ & 36 & 36 & 36 & 36 & 36 & 36 \\
\hline
\end{tabular}

The result of the descriptive statistics shows the common characteristic associated with the variables in the study. The skewness of the variables is asymmentrily distributed and it is positive. For instance, all variables: Per capital income $(\mathrm{PCI})=0.637414$, rural deposit $(\mathrm{RD})=$ 3.089845 , urban deposit (UD) $=1.498064$, rural loans $(\mathrm{Rl})=3.032377$, urban loans $(\mathrm{UL})=$ 2.487290 and, number of banks branches $(\mathrm{NoBB})=$ 5.467567 are positive and has a long tail except for PCI, which has a value $=0.637414$ but normally distributed. Also, the series Kurtosis are all peaked at $>3$, except again for PCI that is flat at $<3$. Similarly, Jarque-Bera statistics show that all series are statistically significant at $<0.05$ percent level except also for PCI that statistically insignificant.

\begin{tabular}{l|l|l|l|l}
\hline \multicolumn{6}{l}{ Table 2, Unit Root Test Result } \\
\hline & Critical Values & ADF & Prob & Order \\
\hline D(PCI) & $1 \%=-3.639407$ & -4.652375 & 0.0007 & $1(1)$ \\
& $5 \%=-2.951125$ & & & \\
& $10 \%=-2614300$ & & & \\
\hline
\end{tabular}

\begin{tabular}{l|l|l|l|l}
\hline $\mathrm{D}(\mathrm{RD})$ & $1 \%=-3.724070$ & -9.856890 & 0.0000 & $\mathrm{I}(1)$ \\
& $5 \%=-2.986225$ & & & \\
& $10 \%=-2.632604$ & & & \\
\hline $\mathrm{D}(\mathrm{UD})$ & $1 \%=-4.252879$ & -4.351358 & 0.0079 & $\mathrm{I}(1)$ \\
& $5 \%=-3.548490$ & & & \\
& $10 \%=-3.207094$ & & & \\
\hline $\mathrm{D}(\mathrm{RL})$ & $1 \%=-3.661661$ & -4.690712 & 0.0007 & $\mathrm{I}(1)$ \\
& $5 \%=-2.960411$ & & & \\
& $10 \%=-2.619160$ & & & \\
\hline $\mathrm{D}(\mathrm{UL})$ & $1 \%=-3.639407$ & -5.317907 & 0.0001 & $\mathrm{I}(1)$ \\
& $5 \%=-2.951125$ & & & \\
& $10 \%=-2.614300$ & & & \\
\hline $\mathrm{D}(\mathrm{NoBB})$ & $1 \%=-3.679322$ & 4.249219 & 1.000 & $\mathrm{I}(0)$ \\
& $5 \%=-2.967767$ & & & \\
& $10 \%=-2.622989$ & & & \\
\hline
\end{tabular}

Essentially, economic variables are often subjected to stationarity status in order to determine their level of state for onward regression estimation path. This study is not different. To confirm the level of the series stationarity, the Augment Dickey Fuller (ADF) unit root stationarity test was conducted. From table 4.2.above, it is clear that growth per capital income (PCI) did not become stationary at level but at first difference. Also, rural deposit (RD), urban deposit (UD), rural loan (RL), and urban loan (UL), became stationary after first differencing, except for number of banks branches (NoBB), which was integrated at level. This outcome, thus, suggest the adoption of autoregressive distributed lag cointegration test as suggested by [26] [27] [28].

\subsection{Autoregressive Distributed Lag Estimates}

To determine the short and long run relationship of the series, the study specified the lag length criteria as indicated below.

\begin{tabular}{|c|c|c|c|c|c|c|}
\hline Lag & $\log \mathrm{L}$ & LR & FPE & AIC & $\mathrm{SC}$ & $\mathrm{HQ}$ \\
\hline 0 & -2006.195 & NA & $1.02 \mathrm{e}+44$ & 118.3644 & 118.6338 & 118.4563 \\
\hline 1 & -1814.515 & 304.4335 & $1.12 \mathrm{e}+40$ & 109.2068 & 111.0923 & 109.8498 \\
\hline 2 & -1681.950 & $163.7562 *$ & $4.71 \mathrm{e}+37^{*}$ & $103.5265^{*}$ & 107.0281* & $104.7207^{*}$ \\
\hline
\end{tabular}

From table 4.3 above, the study performed the lag length selection criteria for possible presence of serial correlation, autocorrelation and heteroskedasticity so as to make the series conform with the standardized stochastic term, using the vector autoregressive unrestricted lag selection criteria [28]. Hence, the table shows that $\operatorname{LR}(-2)^{*}$, $\mathrm{FPE}(-2)^{*}, \mathrm{AIC}(-2)^{*}, \mathrm{SC}(-2)^{*}$ and $\mathrm{HQ}(-2)^{*}$, is 
common to all series thus, suggesting that lag-2 is appropriate.

\begin{tabular}{|c|c|c|c|c|}
\hline Variable & Coefficient & Std. Error & t-Statistic & Prob. \\
\hline$\overline{\mathrm{C}}$ & 50568.57 & 36872.50 & 1.371444 & 0.1854 \\
\hline $\mathrm{D}(\mathrm{PCI}(-2))$ & 0.085904 & 0.272450 & 0.315301 & 0.7558 \\
\hline$\underline{\mathrm{D}(\mathrm{RD}(-2))}$ & -0.648241 & 0.313976 & -2.064617 & 0.0522 \\
\hline $\mathrm{D}(\mathrm{UD}(-2))$ & 11.16840 & 50.68522 & 0.220348 & 0.8278 \\
\hline$\underline{\mathrm{D}(\mathrm{RL}(-2))}$ & 0.024218 & 0.032 & 0.753493 & 0.4599 \\
\hline$\underline{\mathrm{D}(\mathrm{UL}(-2}$ & 108.7224 & 608. & 0.178 & 0.8600 \\
\hline D(NOH & 34.83158 & 12.90074 & 2.699967 & 0.0138 \\
\hline $\mathrm{PCI}(-2)$ & -0.229181 & 0.163359 & -1.402931 & 0.1760 \\
\hline $\mathrm{RD}(-2)$ & 0.611723 & 0.287057 & 2.131020 & 0.0457 \\
\hline $\mathrm{UD}(-2)$ & 37.32741 & 25.54286 & 1.461364 & 0.1595 \\
\hline $\mathrm{RL}($ & -0.057438 & 0.032 & -1.761745 & 0.0934 \\
\hline UL(- & -204.2699 & 675.5213 & -0.302389 & 0.7655 \\
\hline $\mathrm{NOBE}$ & -5.072626 & 8.838586 & -0.573918 & 0.5724 \\
\hline
\end{tabular}

The autoregressive distributed lag - overparameterized result in the short-run is as shown in table 4.4 above. The result shows the existence of thirteen coefficients with their respective probabilities at the short and long-run level individually. From the table and in the short-run, all variables are statistically insignificant except for rural deposit and number of banks branches while; rural deposit shows a statistically significant relationship in the long-run. This result corroborates the importance role rural financial inclusion plays in the overall growth of the economy stated by $[4,5]$. As a consequence, the study diagnosed for probable serial correlation to determine series suitability.

\begin{tabular}{l}
\hline Table 5, Test of Serial Correlation \\
\begin{tabular}{l|l|l}
\hline Breusch-Godfrey Serial Correlation LM Test: \\
\hline F-statistic 1.256997 & Prob. F(2,18) & 0.3083 \\
\hline Obs*R-squared4.044157 & Prob. Chi-Square(2) & 0.1324 \\
\hline
\end{tabular}
\end{tabular}

In an attempt at determining the fitness of the series, the study carried out serial correlation test with the aid of Breusch-Godfrey LM test. From the result, the F-statistics $=0.3083$ indicate that the null hypothesis of no serial correlation is not rejected, having being greater that 0.05 percent level of significant. Hence, the series has no serial correlation and the model is considered fit.

\section{6: Stability Test}

Figure 8, Model Stability - CUSUM Test

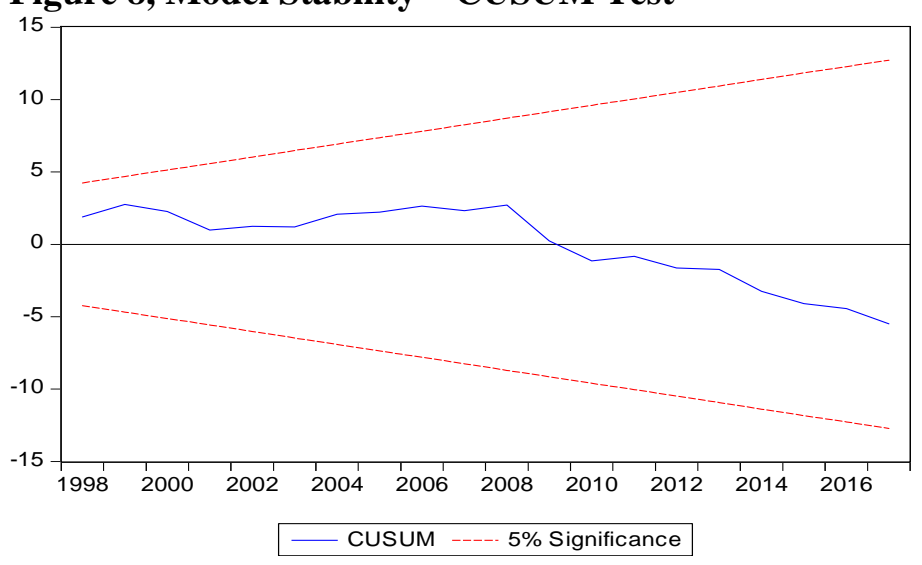

After determining the absence of no serial correlation, the study went further to check for model stability using the cumulative sum (CUSUM) test through recursive estimates of ordinary least square. The cumulative sum helps to affirm change detection of the series whether they wander arbitrary away from the bound line with its respective probability. Since the tracking line is within the bound line, it means that the model is statistically significant at 0.05 percent level hence, the model is stable.

\begin{tabular}{l|l|l|l}
\hline \multicolumn{2}{l|}{ Table 6, Wald/BundTest } & & \\
\hline Test Statistic & Value & df & Probability \\
\hline F-statistic & 1.518094 & $(6,20)$ & 0.2231 \\
\hline Chi-square & 9.108566 & 6 & 0.1676 \\
\hline \hline Null Hypothesis: $\mathrm{C}(8)=\mathrm{C}(9)=\mathrm{C}(10)=\mathrm{C}(11)=\mathrm{C}(12)=\mathrm{C}(13)=0$ \\
\hline Null Hypothesis Summary: & \\
\hline Normalized Restriction $(=0)$ & Value & Std. Err. \\
\hline $\mathrm{C}(8)$ & -0.229181 & 0.163359 \\
\hline $\mathrm{C}(9)$ & 0.611723 & 0.287057 \\
\hline $\mathrm{C}(10)$ & 37.32741 & 25.54286 \\
\hline $\mathrm{C}(11)$ & -0.057438 & 0.032603 \\
\hline $\mathrm{C}(12)$ & -204.2699 & 675.5213 \\
\hline $\mathrm{C}(13)$ & -5.072626 & 8.838586 \\
\hline
\end{tabular}

Restrictions are linear in coefficients.

For the Wald test results, the long-run significant of the variables were checked to determine whether the study's null hypothesis of no long-run relationship, jointly, between the coefficients $\mathrm{c}(8)$, $\mathrm{c}(9), \mathrm{c}(10), \mathrm{c}(11), \mathrm{c}(12)$ and $\mathrm{c}(13)$ is true or equal to zero. Thus, the F-statistics is checked against its bounds critical value to determine the acceptance or rejection of the null hypothesis of no long-run relationship against the table's probability result 
(Pesaran, et al, 2001).As a rule, whenever the calculated F-test is below the lower Bound $\mathrm{I}(0)$, at specified 0.05 percent critical value, then the null hypothesis of no long run relationship is not rejected otherwise, it is rejected when it is higher at upper Bound I(1) level. Thus, since the study calculated F-test $=1.52$ is lower than the critical Bounds level $=4.94$; the null hypothesis is accepted that there is no long run relationship between financial inclusion and economic growth. Some other relevant study can be found in [29].

\section{Conclusions}

The outcome of the study is evident in the display of the nature of relationship existing between financial inclusion and economic growth in Nigeria both in the short-run and in the long-run estimates. There exist mixed results among the variables under review. For instance, the short-run dynamics of financial inclusion against the run-off of growth per capital income, shows that rural deposit (RL), number of banks branches are statistically significant individually in the short-run and; only rural deposit is statistically significant individually in the over-parameterized estimates. This outcome is against that of Wentzel, et al [16]. South Africa, but in-line with [4]. Similarly, the F- statistic from the Wald test result shows that, jointly, there is no long-run relationship between financial inclusion and per capital income in Nigeria. The implication of this is enormous on the sustainable development goals of United Nations, which Nigeria is a stakeholder. Extensive insight into the issues of financial inclusion for sustainable economic growth has been the bane of this study. Like some previous studies, this work also established the vital importance of inclusive financial growth in the country by examining the activities of deposit money banks and regulatory agencies efforts at improving inclusion and overall growth; especially at the rural and among vulnerable groups. In all, the model used in the study is stable and free of serial correlation. It however, showed that financial inclusion impacts on sustainable growth in the short-run but statistically insignificant in the longrun. Based on the findings of the study, it is suggested that direct policies be implemented at improving rural and vulnerable (illiterate) participation in the scheme of things financially, through deliberate establishment of special rural bank, at the rural areas; and to improve secondary financial inclusion participation within the urban areas. It is also suggested that, the process of financial inclusion is a chain like activities that must be nurtured from start to finish

\section{Reference:}

[1] Uronu A. Ndiege B, Rural financial inclusion: Prospects and challenges of collective action in extending financial services among rural smallholders farmers in Tanzania, International Journal of Agricultural Economics, Vol.3, No. 2, 2018, pp. 23-30.

[2] Ogunsakin S, Fawehinmi FO, Financial inclusion as an effective policy tool of poverty alleviation: A case of Ekiti State, Journal of Economics and Finance, Vol.8, No.4, 2017, pp. 01-10.

[3] Shekar M. Veeramani S, Financial inclusion through insurance and pension Schemes, European Business \& Management, Vol.3,No.6, 2018, pp. 105-112.

[4] Babajide AA. Adegboye F.B. Omankhanlen A.E, Financial inclusion and economic growth in Nigeria, International Journal of Economics and Financial Issues, Vol.5, No.3, 2015. Pp. 629-637.

[5] Onaolapo A.R, Effects of financial inclusion on the economy growth of Nigeria (1982 - 2012). International Journal of Business and Management Review, Vol.3, No.8, 2015, pp. 11-28.

[6] Demirguc-Kunt A. Levine RE, Finance financial sector policies, and long run growth M. sperce growth commission Background paper, No.11, 2008, Washington, D.C. World Bank.

[7] Ngo ALN, Index of financial inclusion and the determinants: An investigation in Asia, Asia Economic and Financial Review, Vol.9, No.12, 2019, pp. 1368-2147.

[8] Nguyen TPH, Duong TKL, Effect of earnings management to investor decision: Empirical evidence in Vietnam Stock Market, WSEAS Transaction on Environment and Development, Vol.16, 2020, pp. 84-97

[9] Central Bank of Nigeria, National Financial Inclusion Strategy, 2012.

[10] Egharevba ME, Iruonagbe TC, Azuh, DE, Chiazor AI, Suleiman BM, Poverty, inequality and human development in Nigeria: Appraising the non-attainment of the MDGs, Ife PsychologIA, Vol.24, No.2, 2016, pp. 26-46.

[11] Muhammad T, Dauda SL, Mamman D, The Contemporary Islamic Banking system (Jaiz Bank) in tackling financial exclusion in 
Nigeria, International Journal of Islamic Economics and Finance, Vol.4, No.1, 2018.

[12] Shetty N, Pinto P, Financial exclusion: concept, causes \& consequences A Tridimensional literature analysis. Pezzottaite Journals, Vol.4, No.1, 2015, pp. 79-96.

[13] Tara N, Addressing financial exclusion in France and India: A review of Strategies and Institutions, FMSH-WP-2017, fevrier 2017.

[14]Adeola O, Evans O, The impact of Microfinance on financial inclusion in Nigeria, The Journal of Developing Areas, Vol.51, No.4, 2017.

[15]Andrew L, Shaun F, Paola S, Financial exclusion and the Geography of Bank and

Building Society closure in Britain, Transactions of the Institute of British Geographers, School of Geography, University of Nottingham, Nottingham, 2008.

[16]Wentzel JP, Diatha KS, Yadavalli VS, An investigation into factors impacting financial exclusion at the bottom of the pyramid in South Africa, Development Southern Africa, Vol.33, No.2, pp. 203-214

[17] Central Bank of Nigeria, Statistical Bulletin 2019.

[18] World Bank, Global Findex Database: The little data book on financial inclusion, 2018.

[19] Congo LM, Enquiry into the causes and Effect of Financial Exclusion on the Poor, IMF Working Paper 96/135.Washington International Monetary Fund. Consultative Group to Assists the poor, 2009, Financial Access 2009- measuring Access to Financial services around the World, Technical Report, Washington:(CGAP), 2009.

[20] Osei-Assibey E, Financial exclusion: What Drives supply and demand for basic financial services in Ghana? Savings and Development, Vol.3 No.303, 2009, accessed from: http://ssrn.com/abstract $=1393318$

[21] Chakraborty S, Mukherjee A, Financial inclusion of the poor and marginalized in Jharkhand: Analysis of the existing model. International Journal of Research and Development - A Management Review, Vol.1, No.1, 2012.

[22] Gujarati DN, Porter DC, Basic Econometrics. McGraw Hill 2009

[23] Wooldridge JM, Introductory Econometrics: A modern approach, South-Western Cengage Learning, 2013.
[24]Uppender M, Applied Econometrics, Vrinda Publication, 2008.

[25]Salvatore D, Reagle D, Statistics and Econometrics, McGraw Hill, 2011.

[26] Pesaran MH, Shin Y, An Autoregressive Distributed lag modeling approach to cointegration analysis. Econometrics and Economic Theory in the $20^{\text {th }}$ century: The Ragnar Frisch Centennial Symposium, Cambridge University Press, 1999

[27]Pesaran MH, Shin Y, Smith RJ, Bound testing approaches to the analysis of level relationships, Journal of Applied Econometrics, Vol.16, 2001, pp. 289-326.

[28] Nkoro E, Uko AK, Autoregressive Distributed Lag (ARDL) cointegration technique: Application and interpretation, Journal of Statistical and Econometrics Methods, Vol.5, No.4, 2016, pp. 63-91.

[29] Tingting Ye, Research on the Risk Crisis Prediction of Enterprise Finance by Genetic Algorithm, International Journal of circuits, systems and signal processing, pp. 319-324, Volume 12, 2018 